\title{
Life history and DNA barcode of Oxyurella longicaudis (Birgei, 1910) (Cladocera, Anomopoda, Chydoridae)
}

\author{
Maria Carolina de Almeida Castilho ${ }^{1 *}$, Maria José dos Santos Wisniewski ${ }^{2}$, Cínthia Bruno de Abreu ${ }^{2}$ \\ and Tereza Cristina Orlando ${ }^{2}$
}

\begin{abstract}
Background: Cladocera is an important group of freshwater zooplankton, and the species plays an important role in energy transfer and in aquatic food webs. Oxyurella longicaudis is a Chydoridae species that has been recorded in North and South America. The aim of this study is to investigate the life cycle aspects of parthenogenetic females of $O$. longicaudis cultured in laboratory under controlled conditions: temperature $\left(23^{\circ} \mathrm{C} \pm 05^{\circ} \mathrm{C}\right)$, photoperiod (12 h light/12 h dark), food supply, and reconstituted water.

Results: Embryonic development duration ( $2.3 \pm 0.5$ days), post-embryonic development (5.2 \pm 0.69 days), mean fecundity (two eggs female ${ }^{-1}$ brood $^{-1}$ ), total egg production (22.55 \pm 3.98 eggs), average longevity (58 days), and body growth of the species were recorded. We also report the first DNA barcode for O. longicaudis isolated in Brazil, which will allow for easy identification in future zooplankton community studies. The analysis shows a genetic divergence of around 7\% between our Brazilian isolate and O. Iongicaudis isolates from Mexico.

Conclusions: The time of embryonic and post-embryonic development of $O$. longicaudis was higher than that of the other species of the same family, which contributed to lower total egg production throughout its life cycle. The genetic divergence appears to be sufficient to classify the two isolates as different species.
\end{abstract}

Keywords: Conservation-priority areas; Zooplankton; Bionomics; Cryptic speciation; COI

\section{Background}

Cladocerans participate in energy transfer and aquatic food webs. In lakes and ponds, they represent a link in the food chain by consuming phytoplankton and are preyed upon by other invertebrates and fish (Sarma et al. 2005; Rocha et al. 2011). Cladocerans may be filter feeders, such as family members of Sididae, Moinidae, and Daphnidae or scrapers like the Macrothricidae and Chydoridae (ElmoorLoureiro 2004; Castilho-Noll et al. 2010). The latter family feeds by scraping surfaces of the macrophytes or sediment.

Studies focusing on functional classification of Cladocera species are scarce, and its type of feeding is used for functional classification, so this gap in the literature needs to be addressed (Barnett et al. 2007). Studies have also shown

\footnotetext{
* Correspondence: mariacarolcastilho@gmail.com

'Departamento de Zoologia, Instituto de Biociências, Universidade Estadual Paulista, CP. 510, CEP 18618-000, Botucatu, SP, Brazil

Full list of author information is available at the end of the article
}

that cladocerans' fine mesh filtering apparatus allows them to feed on small protozoa and the microbial flora of aquatic environments or feed on bacteria associated with algae (Geller and Müller 1981; Ooms-Wilms et al. 1995).

According to Frey (1980), representatives of the Chydoridae family are found in the littoral region of water bodies where they live associated with macrophytes, periphyton, and sediment. The distribution of the members of the Chydoridae family is directly related to the presence of macrophytes, most often occurring in specific association (Sacherová and Hebert 2003).

Oxyurella longicaudis is a Chydoridae species recorded in North and South America. In Brazil, they have been recorded in the northeast (Ceará, Pernambuco, Bahia, and Maranhão states), central west (Mato Grosso, Mato Grosso do Sul, and Goiás states), and the southeast (Rio de Janeiro, São Paulo, and Minas Gerais states) 
(Elmoor-Loureiro 2007; Van Damme and Dumont 2010; Rocha et al. 2011; Castilho and Santos-Wisniewski 2013).

This species is rare since it was found in only 3 of 40 water bodies sampled in priority regions for conservation in southern Minas Gerais State (Castilho and SantosWisniewski 2013). This species has been identified in oligotrophic environments and is probably sensitive to environmental changes. O. longicaudis individuals are found in low densities on plankton and have restricted occurrence in coastal regions, where they play a significant role in ecosystem productivity and nutrient cycling (Kotov 2006), serving as a food source for other animals. Considering studies of the coastal region, we may assume that this species may have a wider distribution, demonstrating their role in the aquatic environment.

Studies of the Cladocera life cycle are important because they provide a deeper understanding of the biology of these animals, in addition to providing information on secondary production, population dynamics, and interactions in the food chain in aquatic environments. Ecotoxicology studies aim to control the environmental quality and the ability of zooplankton organisms to swim against a gradient of turbulence (Seuront et al. 2004; Santos-Wisniewski et al. 2002; Freitas and Rocha 2006; Castilho et al. 2012). In Brazil, studies on the life cycle of Chydoridae have been done on species such as Chydorus dentifer and Acroperus harpae, Chydorus pubescens, Coronatella rectangula, and Alona iheringula by Melão (1997), Santos-Wisniewski et al. (2006), Viti et al. (2013), and Silva et al. (2014), respectively. High variation was observed in their life cycle, with a duration average varying between 9 and 46 days, with the greatest longevity recorded for A. iheringula cultured at $25^{\circ} \mathrm{C}$. Although the number of studies has been increasing recently, the knowledge of the taxonomic diversity of Cladocera remains insufficient due to morphological differentiation, phenotypic variation, and historical factors.

Nowadays, molecular identification such as the DNA barcoding has been useful for ecological studies as it allows for precise identification and determination of cryptic species. The DNA barcode includes an analysis of partial sequences of the mitochondrial gene cytochrome oxidase I (COI). Its diversity has been used to identify and detect new species in many animal groups (Hebert et al. 2003), including the Crustacea (Costa et al. 2007; Young et al. 2012). For the Chydoridae, DNA barcoding has already been used to determine some species (Sacherová and Hebert 2003; Gutiérrez et al. 2008; Gutiérrez and Valdez-Moreno 2008; Jeffery et al. 2011; Silva et al. 2014).

The aim of this study is to investigate the aspects of the life cycle of parthenogenic females of O. longicaudis cultured in a laboratory under controlled conditions and characterize its DNA barcode in order to allow for easy identification in future ecological studies.

\section{Methods}

\section{Study area and sampling date}

Sampling was carried out on July 7, 2010 in the Epamig Pond ( $\left.21^{\circ} 56^{\prime} 33^{\prime \prime} \mathrm{S} 45^{\circ} 18^{\prime} 56^{\prime \prime} \mathrm{W}\right)$ situated in a priority area for conservation in Serra da Mantiqueira, Minas Gerais State, Brazil. This pond is oligotrophic, with water which has slightly acidic $\mathrm{pH}$ (5.7), high concentration of dissolved oxygen (9.1 mg. $\mathrm{L}^{-1}$ ), and low electrical conductivity $\left(31 \mu \mathrm{s} . \mathrm{cm}^{-1}\right)$. The pond is shallow and small in size (approximately $60 \times 30 \mathrm{~m}$ ), with an extensive macrophyte stand. The Epamig Pond is located next to the Parque Estadual de Nova Baden. The pond is comprised of a large forest fragment and located near a rice cultivation.

\section{Sampling and acclimatization}

Organisms for starting cultures were collected close to macrophyte stands in the littoral region of the Epamig Pond by horizontal hauls using a zooplankton $68-\mu \mathrm{m}$ mesh size net. In the laboratory, parthenogenetic females of O. longicaudis (Figure 1) were isolated and placed in 2-L beakers containing reconstituted water. This culture medium had $\mathrm{pH}$ 7.6, conductivity $140 \mu \mathrm{s} . \mathrm{cm}^{-1}$ and hardness of $46 \mathrm{mg} . \mathrm{L}^{-1} \mathrm{CaCO}_{3}$. Experimental cultures were maintained in germination chambers (model 347-CDG) at a constant temperature of $23.0^{\circ} \mathrm{C} \pm 0.5^{\circ} \mathrm{C}$ and $12 \mathrm{~h}$-light/ 12 h-dark photoperiod. O. longicaudis was fed a suspension of the small chlorophycean Raphidocelis subcapitata, cultured in Chu 12 medium and cropped in the exponential phase, at a concentration of $10^{5}$ cells. $\mathrm{mL}^{-1}$, and $0.02 \mathrm{~mL}$ of a mixed suspension of yeast, and fish ration added in equal proportions (1:1) (USEPA 1994; ABNT 2009).

\section{Life cycle}

Individuals were acclimated for about ten generations (30 days). Ten females were isolated and maintained until the production of neonates. A total of 30 neonates less than $24 \mathrm{~h}$ old were placed in $50-\mathrm{mL}$ polypropylene bottles and kept in a germination chamber with the temperature, light, and feeding conditions specified above. These organisms were observed to obtain the parameters of the life cycle. Culture media and food suspensions were completely renewed daily with a fresh suspension at the same temperature, once or twice a day. The animals were observed under a stereomicroscope to determine the number of eggs produced per brood and the longevity. The body growth of each individual was measured daily under an optical microscope, using a micrometric grid and $\times 50$ magnification.

\section{DNA barcode}

For the DNA barcode analysis, the specimens were fixed with $95 \% \mathrm{EtOH}$ and placed in pure water for $12 \mathrm{~h}$ for 


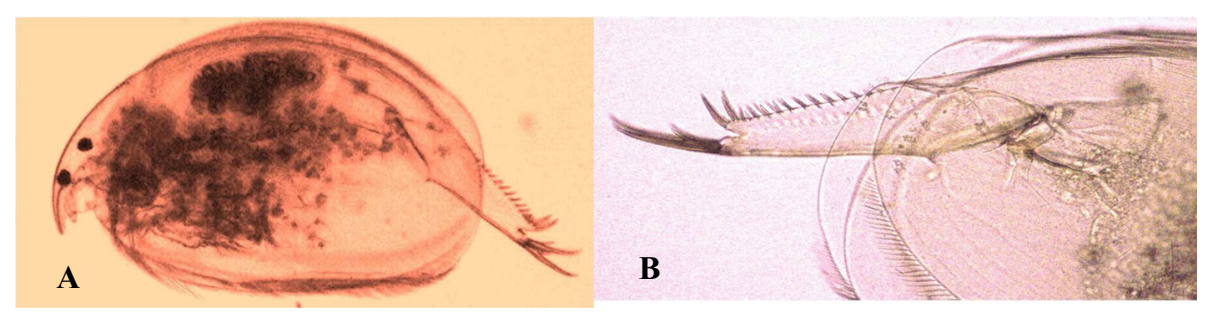

Figure 1 Oxyurella longicaudis from Epamig Pond in Lambari, Minas Gerais state, Brazil. (A) Female, general view (×200). (B) Post-abdomen ( $\times 400)$.

cleaning. Genomic DNA was extracted using phenol extraction and ethanol precipitation (Bucklin 2000). To amplify the mitochondrial COI gene, the universal primers, LCO 1490 and HCO2198 (Folmer et al. 1994) were used. PCR reactions had a total volume of $25 \mu \mathrm{l}$ and were performed according to Ivanova et al. (2009) using Platinum Taq (Invitrogen, Carlsbad, CA, USA) as the enzyme. The PCR conditions were $94^{\circ} \mathrm{C}$ for $2 \mathrm{~min}$ as initial denaturation and 40 cycles of $94^{\circ} \mathrm{C}$ for $40 \mathrm{~s}$, $55^{\circ} \mathrm{C}$ for $40 \mathrm{~s}$, and $72^{\circ} \mathrm{C}$ for $1 \mathrm{~min}$. DNA sequencing was done by direct sequencing of PCR amplification products, carried out in a 3130xl Genetic Analyzer automated DNA sequencer, following the manufacturer's instructions (Applied Biosystems, Foster City, CA, USA). The sequences were obtained bi-directionally two times for accurate reading.

The O. longicaudis COI was aligned in MEGA 6 (Tamura et al. 2013) with other COI sequences that show high sequence similarity using the BLAST tool at Genbank (http://www.ncbi.nlm.nih.gov/pubmed/). The Kimura 2parameter (K2P) distance model (Kimura 1980) was used to calculate sequence divergences. Neighbor-joining (NJ) trees using the K2P method were generated by MEGA 6 (Tamura et al. 2013) facilities. Nonparametric bootstrapping was performed using 1,000 replicates.

\section{Results}

Life cycle

The mean duration of embryonic development was 2.3 days, and the time of post-embryonic development was 5.2 days for $O$. longicaudis. Throughout the life cycle of the species, a mean of 12 broods per female and 22 eggs female ${ }^{-1}$ were produced and the fecundity rate was 2 eggs female ${ }^{-1}$ brood $^{-1}$. The mean longevity was 47 days, and maximum longevity was 58 days (Table 1).

Figure 2 shows mean individual growth curve of the species as a function of time (days). The neonate of $O$. longicaudis had an average size of $504 \mu \mathrm{m}$ and reached maturity with approximately $655 \mu \mathrm{m}$. On average, two juvenile instars and nine instars were recorded throughout the life cycle of the species.

\section{DNA barcode}

The sequence region of the COI gene (barcode region) was $658 \mathrm{bp}$ in length and was deposited as accession number JX501501 in the Genbank. The base composition for $O$. longicaudis COI sequence was as follows: $\mathrm{T}=41.33 \%, \quad \mathrm{C}=13.82 \%, \mathrm{~A}=23.1 \%$, and $\mathrm{G}=21.73 \%$. The calculated A-T content was $64.4 \%$.

A genetic divergence from other $O$. longicaudis from the GenBank was found ranging from $7.0 \%$ to $7.2 \%$ (Table 2). With other Chydoridae species including Oxyurella sp., Kauralona penuelasi, Alona sp., and Alona setulosa, the genetic divergence ranged from $16.8 \%$ to $20.1 \%$.

The NJ tree with $14 \mathrm{COI}$ analyzed sequences shows $O$. longicaudis from Brazil as closely related to seven other O. longicaudis from Mexico (100\% bootstrap support) (Figure 3). For Oxyurella sp., a bootstrap support of $86 \%$ was found with all O. longicaudis and, Alona sp., and A. setulosa were separated as another clade (Figure 3).

Table 1 Life cycle parameters of Oxyurella longicaudis (Cladocera: Chydoridae)

\begin{tabular}{ll}
\hline Life cycle parameters & Values \\
\hline Adult mean size $(\mu \mathrm{m})$ & $883.7 \pm 27.75$ \\
Maximum adult size $(\mu \mathrm{m})$ & 940 \\
Neonate mean size $(\mu \mathrm{m})$ & $503.85 \pm 52.77$ \\
Primipara mean size $(\mu \mathrm{m})$ & $654.61 \pm 45.09$ \\
Minimum size of primipara $(\mu \mathrm{m})$ & 580 \\
Number of instars between neonate and primipara & $1.88 \pm 0.65$ \\
Maximum number of instars in the whole life cycle & $8.92 \pm 1.23$ \\
Mean number of eggs in the whole life cycle & $22.55 \pm 3.98$ \\
Mean fecundity (eggs female ${ }^{-1}$ brood $^{-1}$ ) & 2 \\
Maximum longevity (days) & 58 \\
Mean longevity (days) & $46.96 \pm 9.00$ \\
Mean embryonic development time (days) & $2.30 \pm 0.5$ \\
Primipara age (days) & $5.20 \pm 0.69$ \\
\hline Cultued at $23.0^{\circ} \mathrm{C} \pm 0.5{ }^{\circ} \mathrm{C}$ in a $12-\mathrm{h}$ light/datk photoperiod & $f e d$ on a mixed
\end{tabular}

Cultured at $23.0^{\circ} \mathrm{C} \pm 0.5^{\circ} \mathrm{C}$ in a 12 -h light/dark photoperiod, fed on a mixed suspension of Raphidocelis subcapitata (at $10^{5}$ cells. $\mathrm{mL}^{-1}$ ) and yeast, and fish ration added in equal proportions. 


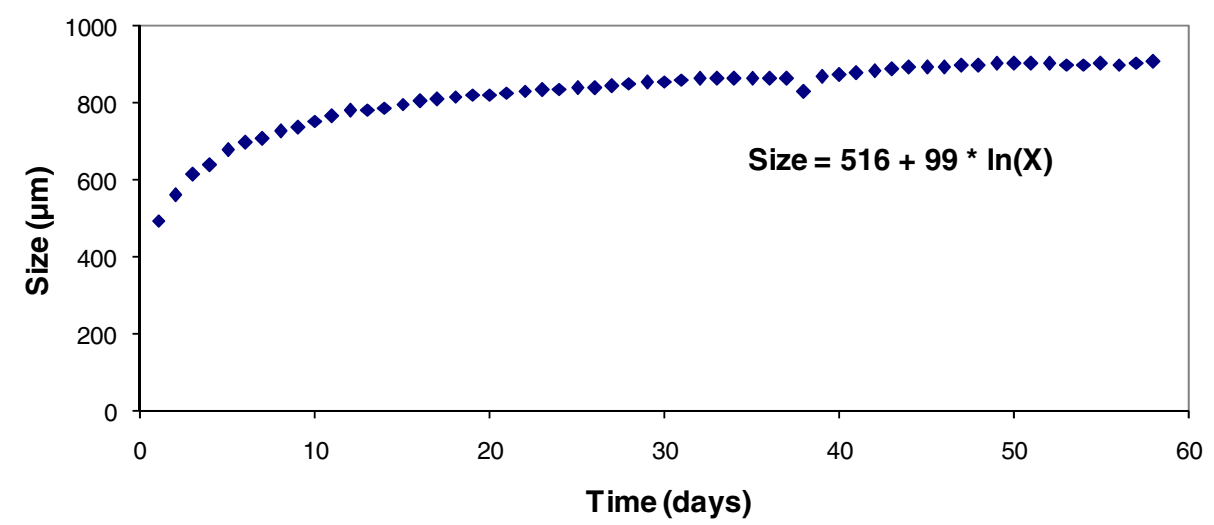

Figure 2 Mean individual growth curve of Oxyurella longicaudis (Cladocera, Chydoridae). Grown in the laboratory at $23.0^{\circ} \mathrm{C}$, in a $12 \mathrm{~h}$-light/ $12 \mathrm{~h}$-dark photoperiod, fed on a mixed suspension of Raphidocelis subcapitata (at 105 cells.mL - 1) and yeast, and fish ration added in equal proportions.

\section{Discussion}

\section{Life cycle of $O$. longicaudis}

O. longicaudis occurred more abundantly in preserved environments, shallow oligotrophic water bodies, with low electrical conductivity, well-oxygenated concentration, and $\mathrm{pH}$ from neutral to alkaline (Rocha et al. 2011; Van Damme and Dumont 2010; Castilho and SantosWisniewski 2013).

Temperature is more important for determining the time of embryonic and post-embryonic development and genetic factors, such species size and size of the egg also influence these parameters. High temperatures promote quick development, while larger eggs take longer time to develop (Melão 1999). The embryonic development time observed for $O$. longicaudis at $23^{\circ} \mathrm{C}(2.3$ days) is greater than that of the other Chydoridae species (Table 3): $A$. iheringula $(510 \mu \mathrm{m})$ has an embryonic development time greater than $O$. longicaudis $(940 \mu \mathrm{m})$ at the same temperature $\left(23^{\circ} \mathrm{C}\right)$. In addition, $C$. rectangula $(468 \mu \mathrm{m})$ was less than $O$. longicaudis at $25^{\circ} \mathrm{C}$, which, at this temperature, reduced the time of embryonic development. $A$. harpae at a higher temperature $\left(25^{\circ} \mathrm{C}\right)$ (Melão 1997) has a shorter embryonic development time and at a lower temperature $\left(20^{\circ} \mathrm{C}\right)$ takes longer in embryonic development (Bottrell 1975).

The post-embryonic development of $O$. longicaudis (5.2 days) was longer than that observed for other representatives of the Chydoridae family. A. harpae, Alonella excisa, Leydigia acanthocercoides, and $A$. iheringula reached maturity on the third day of life (Melão 1997; Sharma and Sharma 1998; Murugan and Job 1982; Silva et al. 2014), and $C$. rectangula reaches primipara age on the second day of life (Viti et al. 2013) (Table 3). By the fifth day of life, O. longicaudis began to show exponential body

Table 2 K2P Genetic distance between COI sequences of Oxyurella longicaudis and other Oxyurella, Kauralona and Alona species

\begin{tabular}{|c|c|c|c|c|c|c|c|c|c|c|c|c|c|c|}
\hline & 1 & 2 & 3 & 4 & 5 & 6 & 7 & 8 & 9 & 10 & 11 & 12 & 13 & 14 \\
\hline \multicolumn{15}{|l|}{ 1. O. longicaudis (JX501501) } \\
\hline 2. O. longicaudis (KC617722) & 0.072 & & & & & & & & & & & & & \\
\hline 3. O. longicaudis (KC617723) & 0.070 & 0.002 & & & & & & & & & & & & \\
\hline 4. O. longicaudis (KC617724) & 0.072 & 0.000 & 0.002 & & & & & & & & & & & \\
\hline 5. O. longicaudis (KC617725) & 0.072 & 0.000 & 0.002 & 0.000 & & & & & & & & & & \\
\hline 6. Oxyurella sp.(KC617135) & 0.168 & 0.153 & 0.151 & 0.153 & 0.153 & & & & & & & & & \\
\hline 7. O. longicaudis (KC617136) & 0.072 & 0.000 & 0.002 & 0.000 & 0.000 & 0.153 & & & & & & & & \\
\hline 8. O. longicaudis (KC617138) & 0.072 & 0.000 & 0.002 & 0.000 & 0.000 & 0.153 & 0.000 & & & & & & & \\
\hline 9. O. longicaudis (KC617139) & 0.070 & 0.002 & 0.000 & 0.002 & 0.002 & 0.151 & 0.002 & 0.002 & & & & & & \\
\hline 10. K. penuelasi (KC617020) & 0.188 & 0.192 & 0.190 & 0.192 & 0.192 & 0.217 & 0.192 & 0.192 & 0.190 & & & & & \\
\hline 11. K. penuelasi (KC617021) & 0.188 & 0.192 & 0.190 & 0.192 & 0.192 & 0.217 & 0.192 & 0.192 & 0.190 & 0.000 & & & & \\
\hline 12. K. penuelasi (KC617022) & 0.188 & 0.192 & 0.190 & 0.192 & 0.192 & 0.217 & 0.192 & 0.192 & 0.190 & 0.000 & 0.000 & & & \\
\hline 13. Alona sp.(KC617433) & 0.181 & 0.197 & 0.195 & 0.197 & 0.197 & 0.184 & 0.197 & 0.197 & 0.195 & 0.208 & 0.208 & 0.208 & & \\
\hline 14. Alona setulosa (EU701997) & 0.201 & 0.209 & 0.206 & 0.209 & 0.209 & 0.227 & 0.209 & 0.209 & 0.206 & 0.204 & 0.204 & 0.204 & 0.198 & \\
\hline
\end{tabular}

Genbank access numbers are located after each species name. 


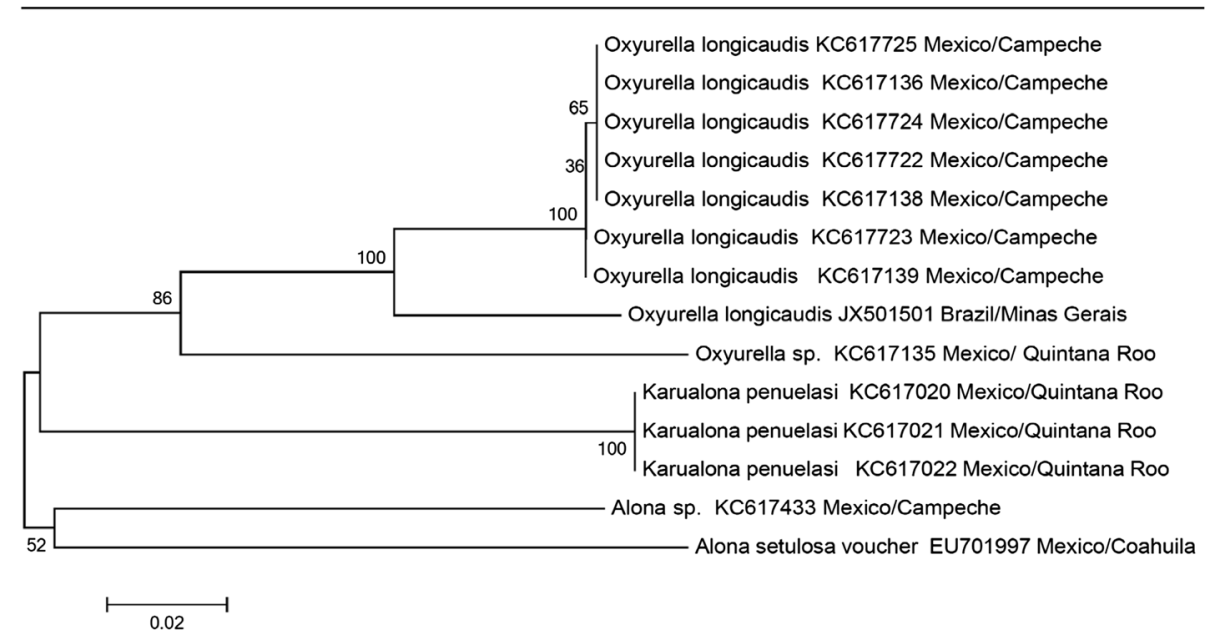

Figure 3 Identification COI tree of Oxyurella and other Oxyurella, Kauralona, and Alona species. Using a 658-bp COI fragment inferred by NJ. Numbers in each node designate percentage of bootstrap support (for 1,000 replicates). The bar shows the number of substitutions per site. Genbank access number and locality are located after each species name.

growth (Figure 2). Therefore, the species began to allocate energy for reproduction only from this period onward, which is indicated by the increase of $O$. longicaudis' body, being larger than most representatives of the Chydoridae family. According to Lynch (1980), larger body species invest almost all of their energy and reproduction after reaching maturity. Additionally, the time duration for post-embryonic development is higher for the Cladocera species with larger bodies under the same feeding conditions (Hardy and Duncan 1994).

The fecundity rate (two eggs brood ${ }^{-1}$ ) found for O. longicaudis is common in representatives of the Chydoridae family (Bottrell 1975; Murugan and Job 1982; Robertson, 1988; Sharma and Sharma 1998; Santos-Wisniewski et al.
2006; Silva et al. 2014). This rate is the lowest fecundity rate between the families of Cladocera. The flat body of Chydoridae members prevents a higher yield of eggs per brood, as occurs with the representatives of other Cladocera families. For example, the Daphnidae Scapholeberis armata freyi produce up to 16 eggs brood ${ }^{-1}$ (Castilho et al. 2012) and the Sididae Pseudosida ramosa produces on average 3.4 eggs brood ${ }^{-1}$ when cultured at $25^{\circ} \mathrm{C}$ (Freitas and Rocha 2006). Moreover, the low fecundity rate of Chydoridae is related to the low levels of population growth of species (Martínez-Jerónimo and GómezDíaz 2011).

Among the cladocerans, small species such as Chydorus and Alona produce 20 eggs female ${ }^{-1}$ on average

Table 3 Comparison of life cycle parameters of Chydoridae species (data from the present study and the literature)

\begin{tabular}{|c|c|c|c|c|c|c|c|}
\hline Species & EDD & PA & $\mathrm{F}$ & CF & L & $\mathrm{T}\left({ }^{\circ} \mathrm{C}\right)$ & Author \\
\hline Oxyurella longicaudis & 2.30 & 5.20 & 2 & 22 & 46.96 & 23 & Present study \\
\hline Chydorus pubescens & 1.96 & 2.37 & 2 & 22.3 & 25.44 & 23.6 & Santos-Wisniewski et al. 2006 \\
\hline Chydorus dentifer & 2.20 & 5.73 & 2 & & 11.39 & 25 & Melão 1997 \\
\hline Chydorus sphaericus & 3.10 & & 2 & & 74 & 20 & Bottrell 1975 \\
\hline Acroperus harpae & 1.56 & 3.70 & 1.59 & & 9.79 & 25 & Melão 1997 \\
\hline Acroperus harpae & 3.18 & & & & 74 & 20 & Bottrell 1975 \\
\hline Pleuroxus uncinatus & 3.16 & & 2 & & & & Bottrell 1975 \\
\hline Alonella excisa & & 3.17 & 2 & 46 & 73.4 & $19-23$ & Sharma and Sharma 1998 \\
\hline Leydigia acanthocercoides & & 3.00 & 2 & 20 & 23.2 & $28-30$ & Murugan and Job 1982 \\
\hline Leydigia ciliata & & & 2 & 50 & 46 & $28-30$ & Venkataraman 1990 \\
\hline Euryalona orientalis & & & 2 & 20 & 23.8 & $28-30$ & Venkataraman 1990 \\
\hline Coronatella rectangula & 1.68 & 2.48 & 1.98 & 27.8 & 28.04 & 23.6 & Viti et al. 2013 \\
\hline Alona iheringula & 1.79 & 3.24 & 2 & 47.6 & 46 & 25 & Silva et al. 2014 \\
\hline
\end{tabular}


during their whole life cycle (Muro-Cruz et al. 2002). The total production of eggs of $O$. longicaudis over the course of its life cycle (22 eggs female ${ }^{-1}$ ) was low compared to other Chydoridae, since it has a longer embryonic development time, and a later primipara. Similar production of eggs has been observed by Santos-Wisniewski et al. (2006) to C. pubescens (22.3 eggs female ${ }^{-1}$ ), by Murugan and Job (1982) to L. acanthocercoides (20 eggs female ${ }^{-1}$ ), and in Euryalona orientalis (20 eggs female ${ }^{-1}$ ) by Venkataraman (1990), and longevity of these species ranged from 23 to 25 days. Longer-lived species such as $A$. excisa (73.4 days) (Sharma and Sharma 1998) and Leydigia ciliata (46 days) (Venkataraman 1990) produced 46 and 50 eggs female $^{-1}$ in their whole life cycle, respectively. A. excisa had a shorter embryonic development time, and $L$. ciliate, grown at a higher temperature by increasing the metabolism of organisms, probably lead to a shorter embryonic development. O. longicaudis stopped producing eggs near the end of its life cycle, contributing to lower total fertility.

The mean size of neonate of $O$. longicaudis was about $50 \%$ less than the maximum size of adults. Smaller species tend to produce offspring with a hatching length closer to their adult size than the larger species (Lynch 1980).

\section{DNA barcode of $O$. longicaudis}

This study established the first barcode region of COI for the Cladocera species O. longicaudis isolated in Brazil. The percentage found for A-T (64.4\%) is consistent with the data range previously described for the $60 \%$ A-T percentage for COI of Chydoridae (Sacherová and Hebert 2003; Belyaeva and Taylor 2009).

One value to consider is the $7.2 \%$ and $7.0 \%$ value of genetic divergence among $\mathrm{O}$. longicaudis from Brazil and the other seven isolates from Mexico. For the Branchiopoda group, a genetic divergence of $3 \%$ in the COI sequence is considered a parameter for distinguishing species at the molecular level. From 3\% to 5\%, the species is considered provisional, and its taxonomic status should be confirmed. Above 5\%, the specimens are considered different species (Jeffery et al. 2011). From this view, a genetic divergence of around 7\% found between our O. longicaudis and the specimens from Mexico should be sufficient to classify them as different species. In order to confirm this and create a new species name, it will be necessary to perform additional morphological detailed studies combined with other molecular markers. However, among all O. longicaudis from Mexico, the genetic divergence ranged from 0 to $0.2 \%$ (Table 2), emphasizing that they represent the same species names.

COI analysis represents an interesting approach to new studies of taxonomy and species recognition of Brazilian isolates as new species, including cryptic species. Also, COI can be used to analyze a zooplankton community to estimate species richness of an entire zooplankton community as already proposed by Machida et al. (2009) and for further phylogeographic studies and gene flow for subpopulations as recently described for copepods (Young et al. 2014). Also, our results using COI markers strengthen the continental endemism idea for Cladocera (Forró et al. 2008; Belyaeva and Taylor 2009) and the monopolization hypothesis for aquatic organisms such as cladocerans (De Meester et al. 2002).

\section{Conclusions}

The embryonic and post-embryonic development times of $O$. longicaudis were higher than those of the other species of the same family, which contributed to lower total egg production throughout its life cycle.

For the DNA barcoding, the roughly $7 \%$ genetic divergence found between our $O$. longicaudis and the specimens from Mexico highlights the possibility of a cryptic speciation for this species and the urgent necessity to clarify the taxonomic position.

\section{Competing interests}

The authors declare that they have no competing interests.

\section{Authors' contributions}

MCAC, TCO, and MJSW conceived and designed the experiments. MCAC and TCO performed the experiments. MCAC, CBA, TCO, and MJSW analyzed the data and wrote the paper. All authors read and approved the final manuscript.

\section{Acknowledgments}

This research was funded by Eletrobrás Furnas (Programa de P\&D Aneel) and FAPEMIG (Biota Minas APQ-03549-09 and Universal APQ 01518-09) grants and a graduate fellowship to C.B.A. (CAPES Program).

\section{Author details}

'Departamento de Zoologia, Instituto de Biociências, Universidade Estadual Paulista, CP. 510, CEP 18618-000, Botucatu, SP, Brazil. 'Instituto de Ciências da Natureza, Universidade Federal de Alfenas-MG, CEP 37130-000, Alfenas, MG, Brazil.

Received: 3 September 2014 Accepted: 30 December 2014 Published online: 20 January 2015

\section{References}

ASSOCIAÇÃO BRASILEIRA DE NORMAS TÉCNICAS - ABNT (2009) NBR 12713: Ecotoxicologia aquática - toxicidade aguda- método de ensaio com Daphnia spp. (Cladocera, Crustacea). ABNT, Rio de Janeiro, p 23

Barnett AJ, Finlay K, Beisner BE (2007) Functional diversity of crustacean zooplankton communities: towards a trait-based classification. Freshw Biol 52:796-813

Belyaeva M, Taylor DJ (2009) Cryptic species within the Chydorus sphaericus species complex (Crustacea: Cladocera) revealed by molecular markers and sexual stage morphology. Mol Phylogenet Evol 50:534-546

Bottrell HH (1975) Generation time, length of life, instar duration and frequency of moulting, and their relationship to temperature in eight species of Cladocera from the river Thames, reading. Oecologia 19:129-140

Bucklin A (2000) Methods for population genetic analysis of zooplankton. In The ICES Zooplankton Methodology Manual, Chapter 11. International Council for the Exploration of the Sea. Academic Press,London 533-570.

Castilho MCA, Santos-Wisniewski MJ (2013) First record of Oxyurella longicaudis (Birgei, 1910) (Cladocera: Chydoridae) in Minas Gerais, southeastern Brazil. Check List 9(3):647-648

Castilho MCA, Wisniewski C, Santos-Wisniewski MJ (2012) Life cycle of Scapholeberis armata freyi Dumont \& Pensaert, 1983 (Cladocera, Daphnidae). Biota Neotropica 12(4):1-5 
Castilho-Noll MSM, Câmara CF, Chicone MF, Shibata EH (2010) Pelagic and littoral cladocerans (Crustacea, Anomopoda and Ctenopoda) from reservoirs of the Northwest of São Paulo State, Brazil. Biota Neotropica 10(1):21-30

Costa FO, DeWaard JR, Boutillier J, Ratnasingham S, Dooh RT, Hajibabaei M, Hebert PDN (2007) Biological identifications through DNA barcodes: the case of the Crustacea. Can J Fish Aquat Sci 64(2):272-295

Elmoor-Loureiro LMA (2004) Phylogenetic relationships among families of the order Anomopoda (Crustacea, Branchiopoda, Cladocera). Zootaxa 760:1-26

Elmoor-Loureiro MLA (2007) Phytophilous cladocerans (Crustacea, Anomopoda and Ctenopoda) from Paranã River Valley, Goiás, Brazil. Revista Brasileira de Zoologia 24(2):344-352

Folmer O, Black M, Hoen W (1994) DNA primers for amplification of mitochondrial cytochrome c oxidase subunit I from diverse metazoan invertebrates. Molec Mar Biol Biotech 3:294-299

Forró L, Korovchinski NM, Kotov A, Petrusek A (2008) Global diversity of cladocerans (Cladocera; Crustacea) in freshwater. Hydrobiologia 595:177-184

Freitas EC, Rocha O (2006) The life cycle of Pseudosida ramosa, Daday 1904, an endemic Neotropical cladoceran. Acta Limnologica Brasiliensia 18(34):293-303

Frey DG (1980) The non-swimming chydorid cladocera of wet forests, with descriptions of a new genus and two new species. Int Revue ges Hydrobiol 65(5):613-641

Geller W, Müller H (1981) The filtration apparatus of Cladocera: filter mesh-sizes and their implications on food selectivity. Oecologia (Berlin) 49:316-321

Gutiérrez EM, Valdez-Moreno M (2008) A new cryptic species of Leberis Smirnov, 1989 (Crustacea, Cladocera, Chydoridae) from the Mexican semi-desert region, highlighted by DNA barcoding. Hydrobiologia 18(1):63-74

Gutiérrez EM, Martínez Jerónimo F, Ivanova NV, Valdez-Moreno M, Hebert PDN (2008) DNA barcodes for Cladocera and Copepoda from Mexico and Guatemala, highlights and new discoveries. Zootaxa 1839:1-42

Hardy ER, Duncan A (1994) Food concentration and temperature effects on life cycle characteristics of tropical Cladocera (Daphnia gessneri Herbst, Diaphanosoma sarsi Richard, Moina reticulata (Daday)): I. Development time. Acta Amazon 24(1/2):119-134

Hebert PDN, Cywinska A, Ball SL, DeWaard JR (2003) Biological identifications through DNA barcodes. Proceedings of the Royal Society of London Series B-Biological Sciences 270(1512):313-321

Ivanova NV, Borisenko AV, Hebert PDN (2009) Express barcodes: racing from specimen to identification. Mol Ecol Resour 9(1):35-41

Jeffery NW, Elías-Gutiérrez M, Adamowicz SJ (2011) Species diversity and phylogeographical affinities of the Branchiopoda (Crustacea) of Churchill, Manitoba, Canada. PLoS ONE 6(5):e18364

Kimura M (1980) A simple method for estimating evolutionary rates of base substitutions through comparative studies of nucleotide sequences. Jol Evol 16(2):111-120

Kotov AA (2006) Adaptations of Anomopoda crustaceans (Cladocera) to the benthic mode of life. Entomol Rev 86(2):210-225

Lynch M (1980) The evolution of Cladocera life history. Quaterly Review of Biology 55(1):21-42

Machida RJ, Hashiguchi Y, Nishida M, Nishida S (2009) Zooplankton diversity analysis through single-gene sequencing of a community sample. BMC Genomics 10:438

Martínez-Jerónimo F, Gómez-Díaz P (2011) Reproductive biology and life cycle of Leydigia louisi mexicana (Anomopoda, Chydoridae), a rare species from freshwater littotal environments. Crustaceana 84(2):187-201

De Meester, L, Gómez A, Okamura B, Schwenk K (2002) The Monopolization Hypothesis and the dispersal-gene flow paradox in aquatic organisms. Acta Oecologica 23(3)121:135

Melão MGG (1997) A comunidade planctônica (fitoplâncton e zooplâncton) e produtividade secundária do zooplâncton de um reservatório oligotrófico. Universidade Federal de São Carlos, São Carlos, Tese de doutorado

Melão, MGG (1999) Desenvolvimento e Aspectos Reprodutivos de Cladóceros e Copépodos de Águas Continentais. In: Pompêo.MLM (org) Perspectivas da Limnologia no Brasil, $1^{a}$ edição, São Luís do Maranhão, MA, Brasil: Gráfica e Editora União 1:45-57

Muro-Cruz G, Nandini S, Sarma SS (2002) Comparative life table demography and population growth of Alona rectangula and Macrothrix triserialis (Cladocera: Crustacea) in relation to algal (Chlorella vulgaris) food density. J Freshw Ecol $17: 1-11$

Murugan N, Job SV (1982) Laboratory studies on the life cycle Leydigia acanthocercoides fisher (1854) (Cladocera: Chydoridae). Hydrobiologia 89:9-16
Ooms-Wilms AL, Postema G, Gulati RD (1995) Evaluation of bacterivory of Rotifera based on measurements of in situ ingestion of fluorescent particles, including some comparisons with Cladocera. J Plankton Res 17:1057-1077

Robertson AL (1988) Life histories of some species of Chydoridae (Cladocera: Crustacea). Freshwather Biology 0:75-84

Rocha O, Santos-Wisniewski MJ, Matsumura-Tundisi T (2011) Checklist de Cladocera de água doce do Estado de São Paulo. Biota Neotropica 1a:1-20

Sacherová V, Hebert PDN (2003) The evolutionary history of the Chydoridae (Crustacea: Cladocera). Biol J Linm Soc 79:629-643

Santos-Wisniewski MJ, Rocha O, Guntzel AM, Matsumura-Tundisi T (2002) Cladocera Chydoridae of high altitude water bodies (Serra da Mantiqueira), in Brazil. Braz J Biol 62(4A):681-687

Santos-Wisniewski MJ, Rocha O, Guntzel AM, Matsumura-Tundisi T (2006) Aspects of the life cycle of Chydorus pubescens Sars, 1901 (Cladocera, Chydoridae). Acta Limnologica Brasiliensia 18:315-333

Sarma SSS, Nandini S, Gulati RD (2005) Life history strategies of cladocerans: comparisons of tropical and temperate taxa. Hydrobiologia 542:315-333

Seuront L, Yamazaki H, Souissi S (2004) Hydrodynamic disturbance and zooplankton swimming behavior. Zool Stud 43(2):376-387

Sharma S, Sharma BK (1998) Observations on the longevity, instar durations, fecundity and growth in Alonella excisa (Fisher) (Cladocera, Chydoridae). Indian J Anim Sci 68:101-104

Silva ES, Abreu CB, Orlando TC, Wisniewski C, Santos-Wisniewski MJ (2014) Alona iheringula Sinev \& Kotov, 2004 (Crustacea, Anomopoda, Chydoridae, Aloninae): life cycle and DNA barcode with implications for the taxonomy of the Aloninae subfamily. Plos One 9:e97050

Tamura K, Stecher G, Peterson D, Filipski A, Kumar S (2013) MEGA6: molecular evolutionary genetics analysis version 6.0. Mol Biol Evol 30:2725-2729

USEPA (1994) Methods for measuring the toxicity and bioaccumulation of sediment-associated contaminants with freshwater invertebrates. Report EPA 600/R-94/024. United States Environmental Protection Agency, Duluth, p 133

Van Damme K, Dumont HJ (2010) Cladocera of the Lençóis Maranhenses (NE - Brazil): faunal composition and a reappraisal of Sars' Method. Braz J Biol 70(3):755-779

Venkataraman K (1990) Life-history studies on some cladoceran under laboratory conditions. J And Sci Assoc 6:127-132

Viti T, Orlando TC, Santos-Wisniewski MJ (2013) Life history, biomass and production of Coronatella rectangular (Branchiopoda, Anomopoda, Chydoridae) from Minas Gerais. Iheringia, Série Zoologia 103(2):110-117

Young SS, Mei-Hui N, Min-Yun L (2012) Systematic Study of the Simocephalus Sensu Stricto Species Group (Cladocera: Daphniidae) from Taiwan by Morphometric and Molecular Analyses. Zoological Studies 51(2):222-231

Young SS, Lee YY, Liu MY (2014) Genetic variability and divergence of Neutrodiaptomus tumidus Kiefer 1937 (Copepoda: Calonida) among 10 subpopulations in the high mountain range of Taiwan and their phylogeographical relationships indicated by mtDNA COI gene. Zool Stud $53: 22$

\section{Submit your manuscript to a SpringerOpen ${ }^{\odot}$ journal and benefit from:}

- Convenient online submission

$\checkmark$ Rigorous peer review

- Immediate publication on acceptance

- Open access: articles freely available online

- High visibility within the field

- Retaining the copyright to your article

Submit your next manuscript at $>$ springeropen.com 